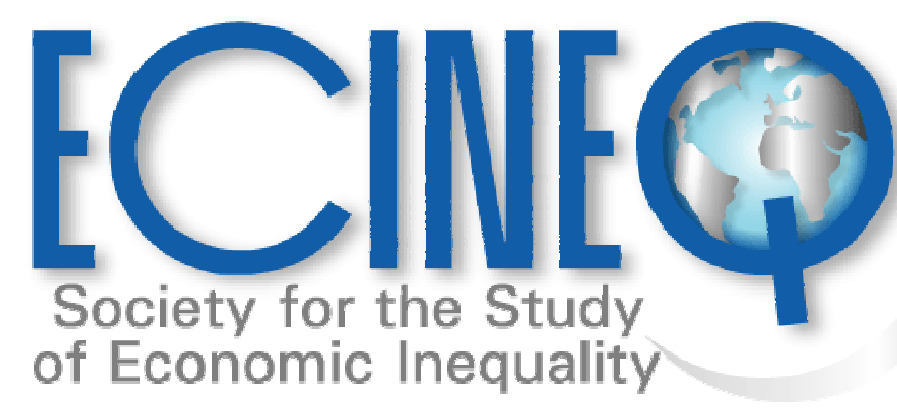

Working Paper Series

Is Fair Trade Honey Sweeter?

An empirical analysis on the effect

of affiliation on productivity

Leonardo Becchetti

Stefano Castriota 


\title{
Is Fair Trade Honey Sweeter? An empirical analysis on the effect of affiliation on productivity ${ }^{*}$
}

\author{
Leonardo Becchetti ${ }^{\dagger}$ \\ University of Rome Tor Vergata \\ Stefano Castriota \\ University of Trento
}

\begin{abstract}
We evaluate the impact of affiliation to Fair Trade on a sample of Chilean honey producers. Evidence from standard regressions and propensity score matching shows that affiliated farmers have higher productivity (income from honey per worked hour) than the control sample. We show that the productivity effect is partially explained by the superior capacity of affiliated workers to exploit economies of scale. Additional results on the effects of affiliation on training, cooperation and advances on payments suggest that affiliation contributed both to, and independently from, the economies of scale effect.
\end{abstract}

Keywords: Fair Trade, economies of scale, productivity.

JEL Classification: D63, D64, O18, O19, O22.

\footnotetext{
* The authors thank for the discussion on fair trade issues F. Adriani, S. Anderson, M. Bagella, K Basu, F. Bourguignon, R. Cellini, L. Debenedictis, M. Fenoaltea, P. Garella, I. Hasan, L. Lambertini, S. Martin, C. McIntosh, N. Phelps, G. Piga and P. Scaramozzino, M E. Tessitore, P. Wachtel, C. Whilborg, H. White, B. Wydick and all participants of seminars held at the XV Villa Mondragone Conference, at SOAS in London, at the Copenhagen Business School and the Universities of Catania, Bologna, Macerata and Milano Bicocca, at the 2008 Poverty and growth network conference in Accra for the useful comments and suggestions received. The usual disclaimer applies. A Council of Rome grant is gratefully acknowledged.

$\dagger$ Address of correspondence: Leonardo Becchetti, University of Rome Tor Vergata, Faculty of Economics, Department of Economics and Institutions, Via Columbia 2, 00133 Rome Italy.
} 


\section{Introduction}

Fair Trade (from now on also FT) may be considered as a general purpose innovation which creates a new line of products. The main characteristic of such products is that of being a bundle of physical and "socially responsible" elements. The socially responsible content of FT goods consists of an original organisation of the product chain and, within it, of the relationship between primary producers, importers, certifiers and retailers. Such distinctive element is formally resumed by FT (IFAT) ${ }^{2}$ rules. The latter documents how Fair Trade schemes aim to use consumption and trade in order to promote inclusion and capacity building of poor farmers in global product markets through a package of benefits which include anti-cyclical mark-ups on prices, producer friendly trade agreements (insurance against price fluctuations, advances on payments,

${ }^{2}$ According to IFAT (the main federation gathering producers and Fair Trade organizations) such criteria are: i) Creating opportunities for economically disadvantaged producers; ii) Transparency and accountability; iii) Capacity building; iv) Promoting Fair Trade; v) Payment of a fair price; vi) Gender Equity; vii) Working conditions (healthy working environment for producers. The participation of children, if any, does not adversely affect their well-being, security, educational requirements and need for play and conforms to the UN Convention on the Rights of the Child as well as the law and norms in the local context); viii) The environment; ix) Trade Relations (Fair Trade Organizations trade with concern for the social, economic and environmental well-being of marginalized small producers and do not maximise profit at their expense. They maintain long-term relationships based on solidarity, trust and mutual respect that contribute to the promotion and growth of Fair Trade. Whenever possible, producers are assisted with access to pre-harvest or pre-production advance payment). 
etc.), long-term relationships, credit facilities and business angel consultancy to build producers' capacity.

In recent times Fair Trade net sales have grown considerably, leading to a mainstreaming of this market phenomenon from its original niche dimension. ${ }^{3}$ The reason for this success is the increasing willingness to pay of "concerned" consumers for the social and environmental characteristics of the products. ${ }^{4} \mathrm{~A}$ main problem in the "Fair Trade economy" is that the value creating intangible, which represents its main innovation, cannot be tasted. This is because the social and environmental content of FT products is not an experience good and the asymmetric information problem between sellers and buyers may be only partially solved with reputational mechanisms and the intermediation of certifiers and labelling organisations. ${ }^{5}$

\footnotetext{
${ }^{3}$ Between 2006 and 2007, total FT sales registered a $127 \%$ increase by volume and $72 \%$ by estimated retail value. Growth in Europe has averaged $50 \%$ per year in the last 6 years. Even though Fair Trade has been originated by not for profit importers (ATOs), this impressive growth has induced traditional corporations to step in. Coop supermarkets in the UK and Italy created their own Fair Trade product lines since the ' $90 \mathrm{es,}$, Nestlè launched its first fair-trade product in 2005. In 2008 Tesco and Sainsbury announced their decision to sell $100 \%$ Fair Trade bananas leading the UK market share for this product to 25 percent (for a discussion on competition between fair trade dedicated retailers and supermarkets see also Kohler, 2007). On September the $3^{\text {rd }} 2008$ Ebay launched a dedicated platform (WorldOfGood.com) for fair trade e-commerce calculating that the U.S. market for such goods was $\$ 209$ billion in 2005 , and foreacasting that it will rise to $\$ 420$ billion in 2010 .

${ }^{4} \mathrm{~A}$ recent inquiry on a representative sample of Italian consumers finds that around $30 \%$ of them are willing to buy FT products even if they have to pay up to $10 \%$ more with respect to non FT equivalent ones (Transfair, 2005). The share rises to around $70 \%$ when the price is the same. Similar results are found in other inquiries in the UK (Bird and Hughes, 1997), Belgium (De Pelsmacker, Driesen and Rayp, 2003) and Germany (www.fairtrade.net/sites/aboutflo/aboutflo).

5 Fairtrade Labelling Organizations International (FLO) is the umbrella organisation of 20 labelling Initatives in Europe as well as Canada, the United States, Japan, Australia and New Zealand. By the end of 2007, there were 632 Fair Trade certified producer organizations in 58 producing countries, representing 1.5 million farmers and workers. With their families and
} 
Given the above mentioned framework, it is easy to understand the importance of methodologically sound impact studies. They can be useful to importers to evaluate, beyond the myth, whether all FT criteria are effectively applied and to understand which factors are more beneficial in terms of producers' inclusion and capacity building. They can be useful to consumers to obtain more information on the socially responsible content of the products and provide sounder grounds to their willingness to pay.

The empirical literature of FT studies is growing and presents, togheter with many valuable case studies (Bacon, 2005; Pariente, 2000; Castro, 2001a and b; Nelson and Galvez, 2000; Ronchi, 2002 and 2006), some econometric analyses which evaluate the impact of affiliation against the benchmark of a control group of non FT producers living in the same areas (Ruben, 2009). Among these papers Ronchi (2006) finds on a panel of 157 mill data that FT helped affiliated Costa Rican coffee producers to increase their market power. The author concludes that FT benefits are of the vertical integration type and that "the decision to support fair trade requires other information about its costs and benefits". Becchetti and Costantino (2008) find that FT affiliates in Kenya enjoy superior product and trade channel diversification, price stability and insurance services. These effects generate social benefits in terms of reduced child mortality, health and social capital (but no significant human capital effects). Becchetti et al. (2008) observe in Peru that years of affiliation details see http://www.fairtrade.net/labelling_initiatives.html. 
significantly increase productivity and self esteem. Consistently with the luxury axiom (Basu, 1998 and 1999), effects on child schooling materialise only after a given threshold of PPP income is overcome. These papers show that FT may create positive or negative externalities in terms of changes of non affiliated producers' wellbeing and improved bargaining power of affiliated producers with local intermediaries.

One of the limits of FT intervention, if not aimed at improving the capacity of affiliated farmers to face market competition, is that it may create a form of dependence from the (volatile) benevolence of socially responsible consumers. ${ }^{6}$ This is the reason why a more accurate empirical analysis (actually missing) on the impact of FT affiliation on capacity building is of foremost importance. The goal of our paper is to provide a contribution in this direction by analysing how some specific characteristics of affiliation (anticipated payments, enhanced interactions between producers and training courses) may affect productivity and transition to the optimal scale of production.

The paper is divided as follows. In the second and third section we briefly sketch the story of the cooperative of producers (Apicoop) affiliated to Fair Trade and the dynamics of honey market, in the fourth section we present descriptive statistics for the full sample and for the subsamples of affiliated and

\footnotetext{
${ }^{6}$ The theoretical debate about pros and cons of Fair Trade revolves around three main points: the discussion on whether the price premium paid to producers is or is not a distortion of market clearing prices, the comparison of the relative efficiency/effectiveness of fair trade versus donations or subsidies, the externalities of Fair Trade introduction on other non affiliated local farmers (for details see Becchetti and Costantino, 2008; Maseland and De Vaal, 2002; Moore, 2004; Hayes, 2004 and Leclair, 2002).
} 
non-affiliated producers. In the fifth section we focus on the effects of affiliation on training courses, cooperation among producers and advances on payments. In the sixth section we present and comment econometric results on productivity. In the seventh section we deal with the selection bias problem. The final section concludes.

\section{History of Apicoop}

During the military dictatorship of the '70s was very difficult and the Church founded several organizations with the objective of helping the economic development of the Dioceses. These institutions were usually financed with foreign donations. For this reason, in 1980 Monsignor José Manuel Santos founded Fundesval (FUNdación DESarrollo VALdivia) with capitals provided by Miserior, a German institution founded in 1958 as agency "against hunger and disease in the world"7.

Fundesval managed six different development projects, one of which was related to honey. ${ }^{8}$ The honey-project pursued three objectives: (i) creating an additional source of income to farmers; (ii) improving the feeding of the population through the consumption of the honey produced; (iii) favoring the

\footnotetext{
7 www.miserior.de.

${ }^{8}$ Chile has a diverse variety of flowers of native species, herbaceous plants and trees that grow only in the central and southern areas of the country. One of these trees is ulmo, which stands out due to its pure white flowers, with extraordinary melliferous qualities. These flowers, so abundant as to make the tree appear covered in snow, are pollinated by bees that use the nectar to produce honey of ulmo, a speciality of northern Patagonia and of the Los Lagos region.
} 
creation of a cooperative society (comité campesino). The first two targets were reached within five years, while the third was realized only in 1998, when the Diocese accepted the request of honey producers associated to the honeyprogram to become independent. In fact, only the honey program was making profits. The profits of the honey-program were used to cover the losses of the others: on average, in the ' 80 s around $28000-30000$ USD were diverted every year. Finally, in 1998 the honey producers took over the honey-program and founded Apicoop, while the five remaining programs were closed.

In order to take over Fundesval, honey producers had to pay the Church a sum of 180,000 USD in current terms. Furthermore, funds were needed to renovate the main office, open the credit lines to farmers and buy new working tools. The honey producers relied on the profits generated by their program in the period 1998-1999, on a 50,000 USD loan provided by CTM Altromercato (an Italian NGO which imports and sells Fair Trade products in Italy) and on two donations of the Province of Bolzano (Northern Italy) which covered $50 \%$ of the renovation costs of the ceiling of the office and of the honey collection room.

The decade 1998-2007 has been a long road towards financial independence with the production of honey enormously increasing and Apicoop becoming the fourth Chilean exporter of honey and the first Chilean producer of Fair Trade honey. At present, the cooperative is made up of 127 beekeeping producers partners (123 individuals and 4 cooperatives), distributed mostly in the Los Lagos region. Apicoop members do not simply benefit from commercialization 
of honey through the cooperative, but receive also free technical assistance, lab tests on the quality of honey and interest-free credit support.

\section{Evolution of prices and volumes in the Chilean export market of honey}

The honey market is subject to significant fluctuations in quantities and prices. As a consequence of significant investments by farmers in Southern Chile, the production and export of honey has increased enormously over the last years. Fluctuations in export quantities and prices are due to sudden shocks to the national production and to the international demand and supply.

A notewhorthy episode in this period is the sudden rise in the period 2002-2004 due to an antibiotic scandal which led the EU to ban the Chinese and Argentinean honey for two years. Once, in 2005, imports from China and Argentina were allowed again, the price fell by more than $40 \%$. The current positive price trend is due to the rising demand not only from developed nations but also from developing ones. China, the biggest honey producer in the world, has increased its per-capita consumption of honey thanks to the rising purchasing power of its citizens, thereby contributing to the positive trend. In such a complex international scenario, FT long-term contracts which stabilize the revenues can be a good insurance for farmers.

\section{Dataset and summary statistics}


Evidence presented in the following sections comes from honey producers, randomly sampled from two sets of treatment and control groups (respectively farmers affiliated and not affiliated to Apicoop) and interviewed in January and February 2008. The questionnaire consisted of a set of standard questions on socio-demographic and economic variables, plus other questions related to the honey production. ${ }^{9}$ The majority of honey producers are men, middle aged, with primary or secondary education, married with children. Almost everybody owns the house he lives in and some land (on average 10 hectares, ranging from 0 to 160). One third of affiliated farmers have no more than 3 affiliation years, while the top third of them more than 10.

The main activity is the production of honey ( $60 \%$ of the sample), but also agriculture and other activities (usually employment in other firms) are important. Worked hours are around 42 per week and approximately half of them are devoted to the production of honey. Average annual total income is five million Pesos (around 6,600 Euros or about 18 dollars per day). ${ }^{10}$ The lowest values of total income and income from honey are equal to zero for young people living with their family who are just starting the honey business. ${ }^{11}$

\footnotetext{
${ }^{9}$ Table 1 describes the variables considered while summary statistics for the whole sample are omitted for reasons of space and available upon request.

10 This standard of living is far higher than what found in other Fair Trade impact studies. Becchetti and Costantino (2008) calculate a standard of living of around 3 dollars in PPP for Meru Herbs famers in Kenya. In Peru, Becchetti et al. (2008) find for the control samples of two producer groups in Juliaca and Chulucanas a standard of living of, respectively, around 0.6 and 6 dollars, against around 2 and 7 dollars for the corresponding samples of affiliated producers. ${ }^{11}$ During the first years of activity all the productive effort is devoted to multiply the number of bee families and honey is not produced.
} 
The simple unweighted average share of honey sold to the FT affiliated cooperative (Apicoop) is equal to 50 percent, the retail share is 31 percent, while shares of output sold to local or international intermediaries are lower than 10 percent. The (wholesale) price of honey sold to the FT affiliated cooperative is obviously lower than the retail price, but surprisingly is also lower than the price paid by local, traditional and international intermediaries. On the other hand, the cooperative provides a set of valuable services: free transport of honey, zero interest advance payments, lab tests on honey chemical properties, training courses, guaranted purchase of a given amount of product which reduces producers' search costs of buyers, etc.

The sample average production of honey per year is 3,200 kilos, but the dispersion is high, ranging from 0 ( 3 new producers with no past yield records met during the interviews $)^{12}$ to 60,000 , with a standard deviation of 6,100 . The average physical productivity (production per weekly hour of work devoted to honey) is 180 kilos. Around 20 percent of producers get advanced payments, whose average is 25 percent of the value of the honey production. Only one individual out of 38 paid interests on the advances (at 20 percent rate), while the others did not pay them since the cash in advance was provided by Apicoop which does not charge anything for this service.

One quarter of the sample lives in towns and the remaining three quarters in the countryside. The majority of individuals live in the area of Santa Barbara,

\footnotetext{
12 These producers are obviously eliminated from the productivity estimates which follow.
} 
Rancagua, Paillaco and Mahiue, the remaining $45 \%$ being spread over several villages.

Honey producers can be classified into three groups: people affiliated to FT (which we call Flo producers), people not affiliated to FT (No Flo producers) and people only indirectly affiliated to FT through another cooperative (Half Flo producers). The first group is made of producers directly associated to the cooperative. The second is made of producers not associated to the cooperative who can, however, sell honey to the cooperative which, in turn, sells it locally. Finally, people indirectly associated through other producer organizations may sell to Apicoop and get the FT price and premium, but not the other services. They are in between the Flo and the No Flo groups. The composition of our sample is such that $46 \%$ of respondents are directly associated to Apicoop, $12 \%$ indirectly through other organizations and $42 \%$ are independent.

Table 2 shows means and confidence intervals of selected variables for the subgroups of FT affiliated (Flo) and independent producers (No Flo). We do not include the intermediate group (Half Flo) to focus on the difference between the two extremes of full and no affiliation, but we will control for their characteristics in the econometric estimates which follow. Double starred values $(* *)$ indicate non overlapping confidence intervals, that is, 95 percent significance of the difference in means between control and treatment groups. ${ }^{13}$ Although most socio-demographic characteristics are similar, there are

\footnotetext{
${ }^{13}$ We run the Wilcoxon nonparametric rank test as a robustness check and obtain the same results in terms of significance. Evidence is omitted and available upon request.
} 
important differences between the two subgroups, especially when looking at the production of honey and at other economic variables.

The three main differences in performance between treatment and control producers concern total yearly income from honey (2,998 against 1,252 thousand of pesos), the quantity of honey produced (4,403 against 1,991 kilos) and productivity measured as income from honey per hour worked (248 against 110 pesos). This implies that affiliated producers are both larger in size and more productive. One of the puzzles which we will try to disentangle is therefore whether FT affiliation has additional benefits in terms of productivity, net of the effect of size, and whether producers progressed in size and economies of scale, also thanks to FT affiliation.

Since inclusion in one of the two (treatment and control) samples is non random but depends on a voluntary choice of producers, we must control whether differences between treated and non treated depend on implicit or explicit selection bias. On the implicit side, producers' characteristics which affected the affiliation decision may also affect performance, irrespectively of the affiliation effect. On the explicit side, it is reasonable to expect that the cooperative selects the most promising candidates to meet the increasingly high quality standards required by international competition. In 2006 this has been made explicit in the statute of Apicoop which now establishes a set of requisites to obtain membership. The most important of them states that the applicant must have at least 3 years of proven production of honey and 25 
beehives. Note however that, exactly for this record of increasing entry standards, we should expect the performance gain to be decreasing in affiliation years (since older producers belong to vintages with less stringent quality requirements). An opposite result would, on the contrary, suggest that this kind of selection bias cannot solely explain the observed differences.

From Table 2 we can see that productivity, production and income from honey are significantly higher for Apicoop members. Our qualitative information from cooperative members tells us that the training courses provided by the association have surely played a role in increasing productivity, particularly under the aspect of reducing bees' diseases and increasing their honey production. Econometric estimates will try to verify these declarations from a quantitative point of view. On the contrary, the price and income per kilo sold are lower for people associated to Apicoop since they produce higher amounts and sell more wholesale (FT chain) rather than retail (local market).

Non affiliated producers sell only 7.5 percent of their production to Apicoop, 57 percent retail and the rest to local or international companies, while people associated to Apicoop sell 82 percent to the cooperative, 14 percent to retail and the remaining to other companies. ${ }^{14}$

The local retail price is lower for Apicoop's members, thus there are no positive externalities of FT affiliation on their bargaining power with local buyers. ${ }^{15}$

\footnotetext{
${ }^{14}$ Apicoop's statute imposes to their members to sell at least 80 percent of their production to them.

${ }^{15}$ Evidence of such externality is provided in Becchetti et al. (2008) for Peruvian FT affiliated in the area of Juliaca (Titicaca lake).
} 
Another surprising element is that the average salary paid by FT entrepreneurs to the temporary workers is lower than that paid by independent ones. This is a common problem with FLO and other FT organizations, whose rules and statutes (see footnote 3) establish minimum prices and premiums for FT members but do not deal with the relationship between producers and their seasonal workers.

\section{Training courses, advances of payments and Marshallian externalities: the difference between affliated and non affiliated producers}

In this section we focus our attention on three qualifying differences between affiliated and non affiliated farmers: advances on payments, attendance of training courses and cooperation with local farmers. Looking at Table 2, only 2 percent of control sample farmers enjoy advances on payments against around 36 percent of Apicoop farmers. 44 percent of non affiliated farmers declare they have not participated to training courses in the last three years, while this is the case for only 22 percent of Apicoop farmers. 87 percent of Apicoop farmers declare to cooperate with other producers in the area, while this occurs for 71 of non affiliated farmers. 95 percent confidence intervals show that these differences in means are significant. Descriptive evidence on these three points is confirmed by econometric analysis (see Table 3) where they are regressed on 
a series of controls. ${ }^{16}$ The specifications include ender, schooling years, family status dummies, number of family members, parents' education, house ownership, land size, total number of hours worked, geographical and type of productive organization dummies.

Our estimates show that affiliation to FLO certificated cooperatives is significantly and negatively correlated with the probability of not having participated to training courses in the last three years (such probability falls by around 32 percent and by 27 percent for directly and indirectly affiliated producers, respectively) ${ }^{17}$ (Table 3 , column 1$) .{ }^{18}$ The same direct affiliation is positive and significant in regressions on the determinants of advances for payment (marginal effect of 50 percent) and declaration to cooperate with other local workers (marginal effect of 12 percent) (Table 3, columns 2 and 3). Consider here that indirect affiliation has slightly higher effects in magnitude, thereby showing that these two last benefits are already attainable with it. ${ }^{19}$ Cooperation is also positively and (weakly) significantly related to the number of hours worked (.2 percent the marginal effect), while advances on payments with schooling years. These associations are reasonable since hard working and committed producers will be more likely, and have more opportunities, to

\footnotetext{
${ }^{16}$ All estimates which follow are with White (1980) heteroskedasticity robust standard errors.

${ }_{17}$ Marginal effect are not displayed in the estimates and calculated, following standad formulas, on the basis of estimated coefficients.

${ }_{18}$ We introduce the two categories with separate regressors since we want to test the different effect of FT on affiliated and indirectly affiliated producers selling to Apicoop at FT conditions.

19 The first finding is consistent with the availability of all price benefits, also to indirectly affiliated producers selling to Apicoop for export in the FT channel.
} 
interact with other producers, while more educated producers should possess higher skills which produce superior creditworthiness.

The effect of FT affiliation has not just a once-for-all effect but also a progressive one. When in our previous specification we replace the affiliation dummy variable with two alternative measures of participation to the FT channel (the length of the relationship with the cooperative and the production share sold to the Apicoop cooperative) we find that years of relationship with Apicoop have positive and significant effects on advances on payments and cooperation with local workers ( 1 and 1.7 percent are the marginal effects of one additional affiliation year on each of the two variables respectively) (Table 3 , columns 4-6). Note as well that years of indirect affiliation (sales to Apicoop without membership) have no significant effects confirming that part of the benefits accrue only to fully affiliated producers.

Our findings are confirmed when we proxy closeness to the cooperative with the share of producers' output sold to Apicoop. The latter has negative (positive) and significant effects on the probability of having never received training courses (obtaining advances on payments) $(-0.2$ and 0.3 percent are, respectively, the two effects for a one percent increase in the share of the product sold to the cooperative).

The variable measuring local interactions among producers may be seen as a proxy of Marshallian externalities if we consider the well known Marshall's 
definition. ${ }^{20}$ If we take into account standard criteria typically adopted in the literature in order to define industrial districts ${ }^{21}$ we may observe that they apply much more to the treatment than to the control sample. Considering the low density and the geographical distance between producers in the rural areas in which we run our survey, cooperative membership is one of the few opportunities to bridge such distance and promote interactions among producers.

\section{Productivity and FT affiliation}

We measure productivity as income from honey production per hour worked and regress it on measures of FT affiliation and various controls (Table 4, columns 1-4). As it will be shown below, the first four specifications are model free, while the two which follow test a specific theoretical assumption. The estimate in column 4 shows that affiliation to $\mathrm{FT}$ is associated with an increase

\footnotetext{
20 "Industry's secrets are ceasing to be secrets: they are, as it where, in the air and children are unwittingly learning many of them. Work well done is immediately recognised and people discuss right away the merits of inventions and improvements made to machines, processes and the general organisation of industry: if somebody comes up with a new idea, it is at once taken over by others and combined with their own home-made suggestions; it this becomes a source of other new ideas" (Marshall, 1920).

21 The main characteristics of industrial districts are generally considered to be: i) the concurring presence of cooperative and competitive features which reduce transaction costs, ii) the high horizontal and vertical mobility of workers (Becattini, 1990), iii) the abundance of exit and voice mechanisms generated by the intensity of productive relationships and interactions between firms and workers within the district (Brusco, 1982; Dei Ottati, 2000), iv) the local abundance of historically accumulated intangible production factors, from (managerial culture, know how, tacit capabilities) (Maillat, 1998), v) the presence of "social networks" (based on kinship, family and localness) which facilitate the flow of knowledge within district borders (Becattini, 1990). The presence of these socially homogeneous communities is expected to foster the intensity of inter-firm cooperation especially under the form of joint programs for the provision of collective goods (Paniccia, 1998) and of creation of local institutions (Lazerson and Lorenzoni, 1999), thereby increasing social capital, which is currently recognised as one of the crucial factors of growth and conditional convergence (Knack and Keefer, 1997).
} 
of 83,186 pesos of honey income per hour worked. It is a remarkable difference if we consider that average honey income per hour worked is 141,302 pesos. Other significant factors are schooling years $(9,645$ pesos per additional year of education), land size (1,429 pesos per hectar), type of productive organization and (weakly) marital status. ${ }^{22}$ The link between our productivity variable and affiliation is confirmed if, instead of the two dummy variables, we use a unique synthetic indicator represented by the share of production sold to Apicoop (Table 4, column 1). A one percent higher share of sales to Apicoop is associated to a gain in farmer's honey income per hour worked of 707 pesos.

The importance of the role of the three above described factors characterizing affiliation (advances on payment, cooperation and training courses) is confirmed when we instrument the affiliation dummy first with years of affiliation (Table 4, column 2) and, after it, with the three factors (Table 4, column 3). The instrumented variable is significant in the second but not in the first case. The Hansen's ] statistic test of overidentifying restrictions does not reject the joint null hypothesis that the instruments are valid instruments, i.e., uncorrelated with the error term. We may wonder whether the affiliation effect is due to the superior capacity of affiliated farmers to reap economies of scale. We therefore make an explicit standard theoretical assumption on the inverse $\mathrm{U}$-shape of the average product function, which implies a U-shaped average

\footnotetext{
${ }^{22}$ The significance of the affiliation variable persists if we limit the estimate to producers hiring seasonal workers and therefore include in the estimate cost of seasonal labour as an additional control. Estimates are omitted for reasons of space and available upon request.
} 
cost function with increasing (decreasing) returns of scale in the downward (upward) side of the curve. As a consequence, we estimate the following specification:

$Y / H=\alpha Y+\beta Y^{2}+\sum_{j} \gamma_{j} X_{j} \quad$ with $\quad H_{0}: a>0, \beta<0$.

Consider as well that, if $y_{j}>0$, this implies that the $\mathrm{j}$-th factor (i.e. FT affiliation) produces a significant perpendicular upward shift of the location of the affected producer from the sample average product curve. Estimates in columns 5 and 6 show that the inverse $\mathrm{U}$-shape assumption is not rejected (both levels and squares of total output are significant and with the expected sign). However, beyond size, years of affiliation (marginal effect of 3,039 pesos per year) and schooling years have an independent positive effect on productivity (even though they are now weakly significant). This implies that FT affiliation years remain significant once we control for the productive scale. It is also interesting to see that the affiliation effect materializes only for fully affiliated producers (or the " $F T$ age half flo" variable, measuring affiliation years of producers selling to Apicoop at FT price conditions without being full cooperative members, is not significant).

Two issues to be discussed in our results are omitted variable bias and measurement error. As it is well known (Deaton, 1997) in development studies the first problem generally relates to the quality of $\operatorname{land}^{23}$ and the second to

\footnotetext{
${ }^{23}$ In this perspective, economies of scale may be a spurious effect driven by a downward bias of the size coefficient when the omitted quality variable is negatively related with size.
} 
measuring income. Since we are looking at honey production, quality of land is not so important, while quality of productive techniques is much more so. The latter are not exogenous since they are affected by training courses and interaction among local producers which, in turn, have been shown to be affected by FT affiliation years. With regard to the measurement error problem, the main candidate in our case is the dependent variable. This creates fewer problems with respect to a measurement error in the regressors and should not alter the sense of our estimates.

\section{Controlling for selection bias: three approaches}

An obvious problem in our model is the lack of dynamics which makes hard to distinguish between the impact of FT affiliation and a selection bias effect. Does affiliation improve productivity and economies of scale, or are more productive and larger farmers more likely to enter the cooperative? We try to provide a qualitative and two quantitative answers to this question. On a qualitative point of view consider that the competitive race in export markets is becoming progressively tighter and international standards of health and product quality regulation increasingly more severe across years. It is therefore highly implausible that Apicoop has affiliated progressively smaller and less efficient producers across years.

Just to give an example of a "vintage" factor (invariant from the first affiliation year to now) which should be correlated with productive skills at the moment of 
entry, we find that average school years of producers with less than 3 years of affiliation in 2007 are 10.44, against 8.37 of those between 6 and 9 years and 7.64 of those above 12 years. This descriptive finding seems consistent with the progressively more severe (land size based) selection criteria described in section 4, assuming the likely correlation between size and producer's education in the entry year.

Hence, the significant effect on a given performance variable of any additional year of affiliation supports the hypothesis of a contribution from the organization and acts against a (vintage driven) selection bias which should operate in the opposite direction by reducing the positive, or even determining a negative, link between years of affiliation and performance.

A first quantitative answer to the selection bias problem is provided by estimating a treatment regression model in which the effect of FT affiliation is controlled for the selection characteristics of affiliates. The treatment regression model shown in Table 5 includes the following two equations ${ }^{24}$ :

$$
\begin{aligned}
& \text { Honeyproductivity } i=a_{0}+a_{1} \text { Age }+a_{2} \text { Education }+a_{3} \text { Hectars }+a_{4} \text { HoursTotal } \\
& +a_{5} \text { YearspreApicoop }+a_{6} \text { House }+a_{7} \text { Flo }+v_{i} \\
& \text { Flo }_{i}=\beta_{0}+\beta_{1} \text { Age }+\beta_{2} \text { Male }+\beta_{3} \text { Married }+\beta_{4} \text { PeopleInHouse }+\beta_{5} \text { Education } \\
& \text { mother }+\beta_{6} \text { Education father }+\Sigma_{k} \delta_{k} \text { Prodstructure }+z_{i}
\end{aligned}
$$

\footnotetext{
${ }^{24}$ In the two equation system ( $v$ ) and ( $\mathrm{z}$ ) are bivariate normal random variables with zero mean and covariance matrix $\left[\begin{array}{cc}\sigma & \rho \\ \rho & 1\end{array}\right]$. The likelihood function for the joint estimation of [1.1] and [1.2] is provided by Maddala (1983) and Greene (2003).
} 
where Prodstructure are $\mathrm{k}$ dummies capturing the organizational form of the producer (family, firm, committee, ${ }^{25}$ lone producer) and Regiondummies capture regional location of the producer.

Note that, to meet the requirement of using selection variables not affecting our performance indicator, in both estimates we use as regressors factors which revealed themselves not correlated with the dependent variable in single equation estimates. Some of these variables are however significant in the selection equation (gender and firm organization). The hypothesis of uncorrelation of residuals of the two equations is not rejected. The affiliation variable remains significant both in the first and in a second specification in which we control for economies of scale by adding the level and square of honey production.

As a further robustness check we finally propose a second approach for evaluating the effect of FT, net of the selection problem (Tables 6.1 and 6.2). As it is well known, in the impossibility of having time series and applying more sophisticated approaches, ${ }^{26}$ propensity score matching $(P S M)^{27}$ may be a reasonable approximation of it. By matching couples of treatment and control producers which are closest in terms of selected characteristics, we may assume with the PSM approach that the average treatment effect of the treated

\footnotetext{
${ }^{25}$ The committee is an informal organization of a small group of individual producers who coordinate their sales and purchases of output in order to obtain higher bargaining power with local intermediaries.

${ }^{26}$ Fair Trade existed in the area before our survey. Therefore it was impossible to perform a randomized experiment on the issue at stake in this paper.

${ }^{27}$ For details on this approach see Dehejia and Wahba (2002), Heckman et al. (1996, 1998), Heckman, Ichimura, and Todd (1997, 1998). See Friedlander, Greenberg, and Robins (1997)
} 
captures the specific contribution of $\mathrm{FT}$ affiliation on the selected performance variable. Following what is standard in the literature when choosing regressors to build the propensity score, we ensure that the vector of variables on which the matching is conditioned is independent from individual assignement to the treatment sample.

We also check that the second crucial condition (distribution of the outcome conditioned on the set of independent variables from the treatment) is met. Consider that our dependent variable is full affiliation and productive scale is introduced among regressors. In this way we make our test more severe since indirectly affiliated producers are in the control sample and the average treatment effect is evaluated at the same level of productive scale. ${ }^{28}$ Obtained findings confirm the difference between affiliated and non affiliated farmers since average treatments of the treated (ATT or differences in means between treatment and control samples) are significant when looking at share of product sold to Apicoop, productivity (income from honey per hours worked), advances on payments and cooperation with local farmers (Tables 6.1 and 6.2 ). ${ }^{29}$

\footnotetext{
${ }^{28}$ Exclusion of indirectly affiliated producers from the test and elimination of the productive scale variables (level and squares of physical production) make differences between treatment and control sample more significant. Results are omitted for reasons of space and available upon request.

${ }^{29}$ What the reader might question at this point is why not all producers choose affiliation given its benefits. The answer should be clear from our results. Less risk averse producers might prefer to take the risk of fluctuating honey prices to the implicit insurance provided by FT. Furthermore, affiliation to a cooperative implies the commitment to sell large part of their production to Apicoop and a series of social obligations that producers with a strong sense of independence may not like. Last but not least, producers not always have full awareness of the potential economic benefits of affiliation.
} 


\section{Conclusions}

The recent literature on impact studies of FT affiliation is important in two respects: i) it gives to consumers of $\mathrm{FT}$ products a test on the validity of the promise to promote inclusion and wellbeing of marginalized producers, thereby reducing the asymmetric information gap between consumers and sellers; ii) it gives relevant insights to importers, labelers and retailers on the application of criteria, emphasizing their strengths and weaknesses and stimulating their discussion and implementation.

Our analysis on Chilean honey producers in a period of high market prices highlights that, beyond the fair price myth, non price conditions are much more important and capable of "Creating opportunities for economically disadvantaged producers" as the first point of IFAT criteria announces. More specifically, the case of Apicoop producers illustrates that FT affiliation, in spite of an insignificant price differential in times of rising market prices, has helped local farmers to improve their productive skills across years. In this process more favourable financial conditions (advances on payments at $0 \%$ interest rate), internalisation of Marshallian externalities via interactions among local producers and training courses are the distinguishing features with respect to a control sample of non affiliated producers which seem to have paid an important role. On the overall, our findings show that affiliation years significantly contribute to increase producers' productivity shifting farmers above the inverse U-shaped average product curve in the sample. 
Among the limits which Fair Trade has to tackle we signal the need for more transparency on full and half membership, the attention to wages of seasonal employees of producers (which is not in the criteria) and the necessity to increase awareness of local cooperative affiliates about Fair Trade.

\section{References}

[1] Bacon, C. (2005), "Confronting the Coffee Crisis: Can Fair Trade, Organic, and Specialty Coffees Reduce Small-Scale Farmer Vulnerability in Northern Nicaragua?", World Development, No. 33(3), pp. 497-511.

[2] Basu, K. (1999), "Child Labor: Cause, Consequence and Cure, with Remarks on International Labor Standards", Journal of Economic literature, Vol. 37, pp. 1083-1119.

[3] Basu, K. \& Van, P.H. (1998), "The Economics of Child Labor" American Economic Review, Vol. 88, pp. 412-427.

[4] Becattini, G., 1990, The Marshallian industrial district as a socio-economic notion, in F. Pyke et al. (eds.), Industrial district and Inter-firm cooperation in Italy, International Institute for Labour Studies, Geneva.

[5] Becchetti, L. \& Costantino, M. (2008), "The Effects of Fair Trade on Marginalised Producers: an Impact Analysis on Kenyan Farmers, World Development, No. 36(5), pp. 823-842.

[6] Becchetti, L., Costantino, M. and Portale, E. (2008), "Human capital, externalities and tourism: three unexplored sides of the impact of FT affiliation on primary producers", CEIS working paper No. 262.

[7] Bird, K. and D.R. Hughes (1997), "Ethical Consumption: The Case of 'Fairly-Traded' Coffee", Business Ethics, No. 6(3), pp. 159-167.

[8] Brusco, S. (1982), "The Emilian Model: Productive Decentralization and Social Integration", Cambridge Journal of Economics, Vol. 6 (2).

[9] Castro, J.E. (2001a), "Impact assessment of Oxfam's fair trade activities. The case of Productores de miel Flor de Campanilla", Oxford: Oxfam.

[10] Castro, J.E. (2001b), "Impact assessment of Oxfam's fair trade activities. The case of COPAVIC", Oxford: Oxfam.

[11] Deaton, A. (1997), "The Analysis of Household Surveys: A Microeconometric Approach to Development Policy", The Johns Hopkins University Press (for the World Bank). 
[12] Dehejia, R. H. \& Wahba, S. (2002) "Propensity Score-Matching Methods for Nonexperimental Causal Studies", The Review of Economics and Statistics, Vol. 84(1), pp. 151-161.

[13] Dei Ottati, G. (2000), "Exit, Voice, and Loyalty in the Industrial District: The Case of Prato", University of Cambridge, ESRC Centre for Business Research, Working Paper WP175.

[14] De Pelsmacker P. \& L. Driesen \& G. Rayp (2003), "Are Fair Trade Labels Good Business? Ethics and Coffee Buying Intentions", Working Papers of Faculty of Economics and Business Administration, Ghent University.

[15] Friedlander D., Greenberg D. H. \& Robins P. K., (1997), "Evaluating Government Training Programs for the Economically Disadvantaged," Journal of Economic Literature, Vol. 35(4), pp. 1809-1855.

[16] Greene, W. (2003), "Econometric Analysis", 5th Edition, Prentice Hall.

[17] Hayes, M. (2004), "Strategic Management Implication of the Ethical Consumer", www.fairtraderesearch.org.

[18] Heckman, J., Ichimura, H. \& Todd, P. (1997), "Matching as an Econometric Evaluation Estimator: Evidence from Evaluating a Job Training Programme", Review of Economic Studies, No. 64(4), pp. 605654.

[19] Heckman, J., Ichimura, H. \& Todd, P. (1998), "Matching as an Econometric Evaluation Estimator", Review of Economic Studies, No. 65(2), pp. 261-294.

[20] Heckman et al. (1996), "Sources of Selection Bias in Evaluating Social Programs: An Interpretation of Conventional Measures and Evidence on the Effectiveness of Matching as a Program Evaluation Method", Proceedings of the National Academy of Sciences, No. 93:23, pp. 1341613420.

[21] Heckman et al. (1998), "Characterizing Selection Bias Using Experimental Data," Econometrica, No. 66:5, pp. 1017-1098.

[22] Kohler P. (2007), "The Economics of Fair Trade: For Whose Benefit? An Investigation into the Limits of Fair Trade as a Development Tool and the Risk of Clean-Washing", HEI Working Paper 06-2007.

[23] Knack, S. \& Keefer, P. (1997), "Does Social Capital Have an Economic Payoff? A Cross-Country Investigation", Quarterly Journal of Economics, Vol. 112, pp. 1251-88.

[24] Leclair, M. S. (2002), "Fighting the Tide: Alternative Trade Organizations in the Era of Global Free Trade", World Development, Vol. 30(7), pp. 1099-1122.

[25] Lazerson, M. H. \& Lorenzoni, G. (1999), "The Firms that Feed Industial Districts: A Return to the Italian Source", Industrial and Corporate Change, Vol. 8, pp. 36-47.

[26] Maddala, G. S. (1983), "Limited-Dependent and Qualitative Variables in Econometrics", Econometric Society Monographs in Quantitative Economics, Cambridge University Press. 
[27] Maillat, D. (1998), "From the Industrial District to the Innovative Milieu: Contribution to an Analysis of Territorialised Productive Organizations", Recherches Economiques de Louvain, 64(1), pp. 111-129.

[28] Marshall, A. (1920), "Principles of Economics", Macmillan, London.

[29] Maseland, R. \& De Vaal, A. (2002), "How Fair is Fair Trade?", De Economist, 150(3), 251-272.

[30] Moore, G. (2004), "The Fair Trade Movement: Parameters, Issues and Future Research", Journal of Business Ethics, Vol. 53(1-2), pp. 73-86.

[31] Nelson, V. \& Galvez, M. (2000), "Social Impact of Ethical and Conventional Cocoa Trading on Forest-Dependent People in Ecuador". University of Greenwich, mimeo

[32] Paniccia, I. (1998), "One, a Hundred, Thousands of Industrial Districts", Organization Studies, 19(4), pp. 667-699.

[33] Pariente, W. (2000), "The Impact of Fair Trade on a Coffee Cooperative in Costa Rica. A Producers Behaviour Approach", Université Paris I Panthéon Sorbonne.

[34] Ronchi, L. (2002), "The Impact of Fair Trade on Producers and their Organizations: a Case Study with Coocafè in Costa Rica", University of Sussex. mimeo

[35] Ronchi, L. (2006) "Fairtrade" and Market Failures in Agricultural Commodity Markets. World Bank Policy Research Working Paper 4011. Washington: IBRD.

[36] Ruben, R., (2009), The impact of fair trade, Wageningen Academic Publishers, Wageningen

[37] White, H. (1980), "A Heteroskedasticity-Consistent Covariance Matrix and a Direct test for Heteroskedasticity", Econometrica, Vol. 48, pp. 817-38. 
Table 1. Variables definition

\begin{tabular}{|c|c|c|c|}
\hline Variable & Description & Variable & Description \\
\hline Male & DV equal to 1 if the respondent is male & $\begin{array}{l}\text { Sale to international } \\
\text { intermediaries }\end{array}$ & Share of honey sold to international intermediaries \\
\hline Age & Age in years & Price Apicoop & Price paid by Apicoop \\
\hline Education & Years of school attendance & Price retail & Retail price \\
\hline Education mother & Education of the mother in years & $\begin{array}{l}\text { Price local intermediaries } \\
\text { Price traditional }\end{array}$ & Price paid by local intermediaries \\
\hline Education father & Education of the father in years & $\begin{array}{l}\text { intermediaries } \\
\text { Price international }\end{array}$ & Price paid by traditional intermediaries \\
\hline Married & DV equal to 1 if the respondent is married & intermediaries & Price paid by international intermediaries \\
\hline Single & $\begin{array}{l}\text { DV equal to } 1 \text { if the respondent is single } \\
\text { DV equal to } 1 \text { if the respondent lives with }\end{array}$ & Price per kilo & Price of honey per kilo \\
\hline Living together & the partner & Honey production & Total production of honey in kilos \\
\hline Divorced & $\begin{array}{l}\text { DV equal to } 1 \text { if the respondent is divorced } \\
\text { DV equal to } 1 \text { if the respondent is }\end{array}$ & Productivity per hour & $\begin{array}{l}\text { Value of honey prodution per hour worked } \\
\text { DV equal to } 1 \text { if the respondent received advance }\end{array}$ \\
\hline Separated & separated & Advance payment & $\begin{array}{l}\text { payments } \\
\text { Percentage of the value of the honey production }\end{array}$ \\
\hline Widowed & DV equal to 1 if the respondent is widowed & Percentage advance & received in advance \\
\hline Children & Number of children & Interests on advance & $\begin{array}{l}\text { Interest rate applied to advance payments } \\
\text { DV equal to } 1 \text { if the respondent attended training }\end{array}$ \\
\hline People in house & Number of people living in the household & Training courses & courses in the last 3 years \\
\hline Hectars & $\begin{array}{l}\text { Property of land in hectars } \\
\text { DV equal to } 1 \text { if the respondent owns the }\end{array}$ & Loan & $\begin{array}{l}\text { DV equal to } 1 \text { if the respondent received a loan last year } \\
\text { DV equal to } 1 \text { if the respondent was able to save some }\end{array}$ \\
\hline House & house & Savings & $\begin{array}{l}\text { money last year } \\
\text { DV equal to } 1 \text { if the respondent faced credit restrictions }\end{array}$ \\
\hline Honey & DV if honey is the main economic activity & Credit restriction & $\begin{array}{l}\text { last year } \\
\text { DV equal to } 1 \text { if the producer declares to cooperate with }\end{array}$ \\
\hline Other bees & $\begin{array}{l}\text { main economic activity } \\
\text { DV if agriculture is the main economic }\end{array}$ & Cooperation & $\begin{array}{l}\text { other producers in the area } \\
\text { Average hourly wage of workers employed over the }\end{array}$ \\
\hline Agriculture & $\begin{array}{l}\text { activity } \\
\text { DV if breeding is the main economic }\end{array}$ & Wage permanent worker & whole year \\
\hline Breeding & $\begin{array}{l}\text { activity } \\
\text { DV if the main economic activity is not one }\end{array}$ & Wage temporary worker & Average hourly wage of seasonal workers \\
\hline Other activity & of those mentioned above & Happiness & Self declared happiness level (from 1 to 10 ) \\
\hline Hours total & $\begin{array}{l}\text { Number of hours devoted to working } \\
\text { activities in general } \\
\text { Number of hours devoted to the production }\end{array}$ & Family satisfaction & $\begin{array}{l}\text { Self declared satisfaction with economic conditions of } \\
\text { the family (from } 1 \text { to } 10 \text { ) }\end{array}$ \\
\hline Hours honey & of honey & Town & DV equal to 1 if the respondent lives in town \\
\hline Hours agriculture & Number of hours devoted to agriculture & Santa Barbara & DV equal to 1 if the respondent lives in Santa Barbara \\
\hline Hours breeding & $\begin{array}{l}\text { Number of hours devoted to breeding } \\
\text { Number of hours devoted to other }\end{array}$ & Paillaco & DV equal to 1 if the respondent lives in Paillaco \\
\hline Hours other & economic activities & Rancagua & DV equal to 1 if the respondent lives in Rancagua \\
\hline Income necessary & Income considered necessary to live well & Mahiue & DV equal to 1 if the respondent lives in Mahiue \\
\hline Income total & Total income earned last year & Lone producer & $\begin{array}{l}\text { DV equal to } 1 \text { if the respondent produces honey alone } \\
\text { DV equal to } 1 \text { if the respondent produces honey with }\end{array}$ \\
\hline Income honey & Income from honey last year & Family & $\begin{array}{l}\text { the family } \\
\text { DV equal to } 1 \text { if the respondent created a company to }\end{array}$ \\
\hline Income bees & Income from other bees' products last year & Company & $\begin{array}{l}\text { produce honey } \\
\text { DV equal to } 1 \text { if the respondent belongs to a honey }\end{array}$ \\
\hline Income agriculture & Income from agriculture last year & Committee & $\begin{array}{l}\text { committee } \\
\text { Years of affiliation to a cooperative before the birth of }\end{array}$ \\
\hline Income breeding & Income from breeding last year & Years pre Apicoop & $\begin{array}{l}\text { Apicoop } \\
\text { DV equal to } 1 \text { if the respondent is directly associated to }\end{array}$ \\
\hline Income other & Income from other activities last year & Flo & $\begin{array}{l}\text { FT cooperatives } \\
\text { DV equal to } 1 \text { if the respondent is not affiliated to }\end{array}$ \\
\hline Other sources & $\begin{array}{l}\text { DV equal to } 1 \text { if the respondent has other } \\
\text { sources of income }\end{array}$ & Half Flo & $\begin{array}{l}\text { Apicoop but sells part of its production to Apicoop for } \\
\text { the FT export channel enjoying the FT price benefits } \\
\text { DV equal to } 1 \text { if the respondent is neither a Flo nor an }\end{array}$ \\
\hline Sale Apicoop & Share of honey sold to Apicoop & No Flo & $\begin{array}{l}\text { Half Flo producer (not affiliated to Apicoop and not } \\
\text { selling to Apicoop for the FT export channel) }\end{array}$ \\
\hline Sale retail & Share of honey sold to retail & FT age flo & Number of affiliation years of Apicoop members \\
\hline $\begin{array}{l}\text { Sale local intermediaries } \\
\text { Sale traditional } \\
\text { intermediaries }\end{array}$ & $\begin{array}{l}\text { Share of honey sold to local intermediaries } \\
\text { Share of honey sold to traditional } \\
\text { intermediaries }\end{array}$ & FT age half flo & $\begin{array}{l}\text { Number of years of trade relationships of non affiliated } \\
\text { members selling to Apicoop for the FT export channel }\end{array}$ \\
\hline
\end{tabular}


Table 2. Confidence intervals of selected variables for treatment (Flo certified producers) and control samples

\begin{tabular}{|c|c|c|c|c|c|c|c|c|}
\hline \multirow[b]{2}{*}{ Variable } & \multicolumn{4}{|c|}{ No Flo } & \multicolumn{4}{|c|}{ Flo } \\
\hline & Obs & Mean & [95\% Conf. & Interval] & Obs & Mean & [95\% Conf. & Interval] \\
\hline Male & 98 & 0.78 & 0.69 & 0.86 & 108 & 0.89 & 0.83 & 0.95 \\
\hline Age & 98 & 48.29 & 45.62 & 50.95 & 108 & 50.60 & 48.42 & 52.78 \\
\hline Education & 98 & 10.35 & 9.49 & 11.20 & 107 & 9.46 & 8.69 & 10.23 \\
\hline Children & 97 & 2.47 & 2.10 & 2.85 & 106 & 2.66 & 2.28 & 3.05 \\
\hline Hectars & 98 & 11.83 & 6.28 & 17.37 & 107 & 8.26 & 4.44 & 12.08 \\
\hline House & 98 & 0.88 & 0.81 & 0.94 & 108 & 0.91 & 0.85 & 0.96 \\
\hline \multicolumn{9}{|l|}{ Main activity } \\
\hline Honey & 98 & $0.49 * *$ & 0.39 & 0.59 & 108 & $0.69 * *$ & 0.60 & 0.77 \\
\hline Other bees & 98 & 0.03 & 0.00 & 0.07 & 108 & 0.00 & 0.00 & 0.00 \\
\hline Agriculture & 98 & $0.19 * *$ & 0.11 & 0.27 & 108 & $0.06 * *$ & 0.02 & 0.11 \\
\hline Breeding & 98 & 0.06 & 0.01 & 0.11 & 108 & 0.07 & 0.02 & 0.12 \\
\hline Other activity & 98 & 0.23 & 0.15 & 0.32 & 108 & 0.18 & 0.10 & 0.25 \\
\hline \multicolumn{9}{|l|}{ Hours worked } \\
\hline Hoours total & 97 & 40.79 & 37.10 & 44.49 & 107 & 42.40 & 39.13 & 45.68 \\
\hline Hours honey & 98 & 14.89 & 12.07 & 17.71 & 108 & 20.32 & 17.62 & 23.03 \\
\hline Hours agriculture & 98 & 9.16 & 6.30 & 12.03 & 108 & 5.90 & 3.66 & 8.14 \\
\hline Hours breeding & 98 & 3.42 & 1.18 & 5.66 & 108 & 4.55 & 2.52 & 6.57 \\
\hline Hours other & 97 & 10.62 & 6.86 & 14.38 & 108 & 9.92 & 6.67 & 13.16 \\
\hline \multicolumn{9}{|c|}{ I ncome and productivity } \\
\hline Income necessary & 98 & $5,177,143$ & $4,263,280$ & $6,091,006$ & 107 & $4,308,785$ & $3,771,018$ & $4,846,552$ \\
\hline Income total & 95 & $4,399,368$ & $2,218,092$ & $6,580,645$ & 108 & $5,787,667$ & $3,266,378$ & $8,308,955$ \\
\hline Income honey & 94 & $1,251,649 * *$ & 860,207 & $1,643,091$ & 107 & $2,998,411 * *$ & $1,997,739$ & $3,999,084$ \\
\hline Other souces & 95 & 0.69 & 0.60 & 0.79 & 102 & 0.54 & 0.44 & 0.64 \\
\hline Honey production & 95 & $1,991 * *$ & 1,208 & 2,774 & 103 & $4,403 * *$ & 2,867 & 5,940 \\
\hline Productivity per hour & 94 & $110 * *$ & 81 & 140 & 103 & $248 * *$ & 168 & 328 \\
\hline
\end{tabular}


Table 2. Confidence intervals of selected variables for treatment (flo certified producers) and control samples (follows)

\begin{tabular}{|c|c|c|c|c|c|c|c|c|}
\hline \multirow[b]{2}{*}{ Variable } & \multicolumn{4}{|c|}{ No Flo } & \multicolumn{4}{|c|}{ Flo } \\
\hline & Obs & Mean & [95\% Conf. & [ nterval] & Obs & Mean & [95\% Conf. & I nterval] \\
\hline \multicolumn{9}{|c|}{ Price, sales and financial conditions } \\
\hline Sale Apicoop & 98 & $7.50 * *$ & 2.59 & 12.41 & 108 & $81.61 * *$ & 77.10 & 86.12 \\
\hline Sale retail & 98 & $56.87 * *$ & 47.51 & 66.23 & 108 & $14.38 * *$ & 10.32 & 18.44 \\
\hline Sale local intermediaries & 98 & $11.42 * *$ & 5.40 & 17.44 & 108 & $0.69 * *$ & -0.10 & 1.49 \\
\hline Sale traditional intermediaries & 98 & $18.17 * *$ & 10.73 & 25.62 & 108 & $0.83 * *$ & -0.08 & 1.75 \\
\hline Sale international intermediaries & 98 & $1.76 * *$ & -0.70 & 4.21 & 108 & $0.28 * *$ & -0.27 & 0.83 \\
\hline Price Apicoop & 10 & 754 & 720 & 788 & 101 & 764 & 753 & 774 \\
\hline Price retail sales & 67 & $1,663 * *$ & 1,565 & 1,761 & 70 & $1,461 * *$ & 1,368 & 1,554 \\
\hline Price local intermediaries & 20 & 818 & 730 & 905 & 3 & 1,533 & -64 & 3,130 \\
\hline Price traditional intermediaries & 14 & 792 & 730 & 854 & 3 & 1,133 & 374 & 1,892 \\
\hline Price international intermediaries & 2 & 915 & $-1,436$ & 3,266 & 1 & 1,500 & . & . \\
\hline Loans & 98 & 0.70 & 0.61 & 0.80 & 105 & 0.80 & 0.72 & 0.88 \\
\hline Savings & 97 & 0.55 & 0.45 & 0.65 & 108 & 0.57 & 0.48 & 0.67 \\
\hline Wage permanent & 2 & 850 & $-3,597$ & 5,297 & 10 & 822 & 575 & 1,069 \\
\hline $\begin{array}{l}\text { Wage temporary } \\
\text { Cooperative services }\end{array}$ & 36 & $1,012 * *$ & 906 & 1,117 & 45 & $843 * *$ & 789 & 897 \\
\hline Never attended training courses & 98 & $0.438 * *$ & 0.338 & .5387 & 86 & $.244 * *$ & .151 & .336 \\
\hline Cooperation & 98 & $0.714 * *$ & 0.623 & 0.805 & 87 & $.873 * *$ & .802 & .944 \\
\hline Advance payment & 94 & $0.02 * *$ & -0.01 & 0.05 & 107 & $0.36 * *$ & 0.26 & 0.45 \\
\hline Percent advance & 1 & $10 * *$ & . & . & 35 & $23.20 * *$ & 16.93 & 29.47 \\
\hline Interests on advance & 1 & $20 * *$ & . & . & 32 & $0.09 * *$ & -0.10 & 0.28 \\
\hline
\end{tabular}

**: the difference in mean among the two groups is significant at $5 \%$ level. Producers only indirectly affliated to Apicoop (Half Flo) are ruled out from the sample in order to focus on differences between full and no affiliation. 


\section{Table 3. Training courses, cooperation and advances on payments: the role of $\mathrm{FT}$ affiliation}

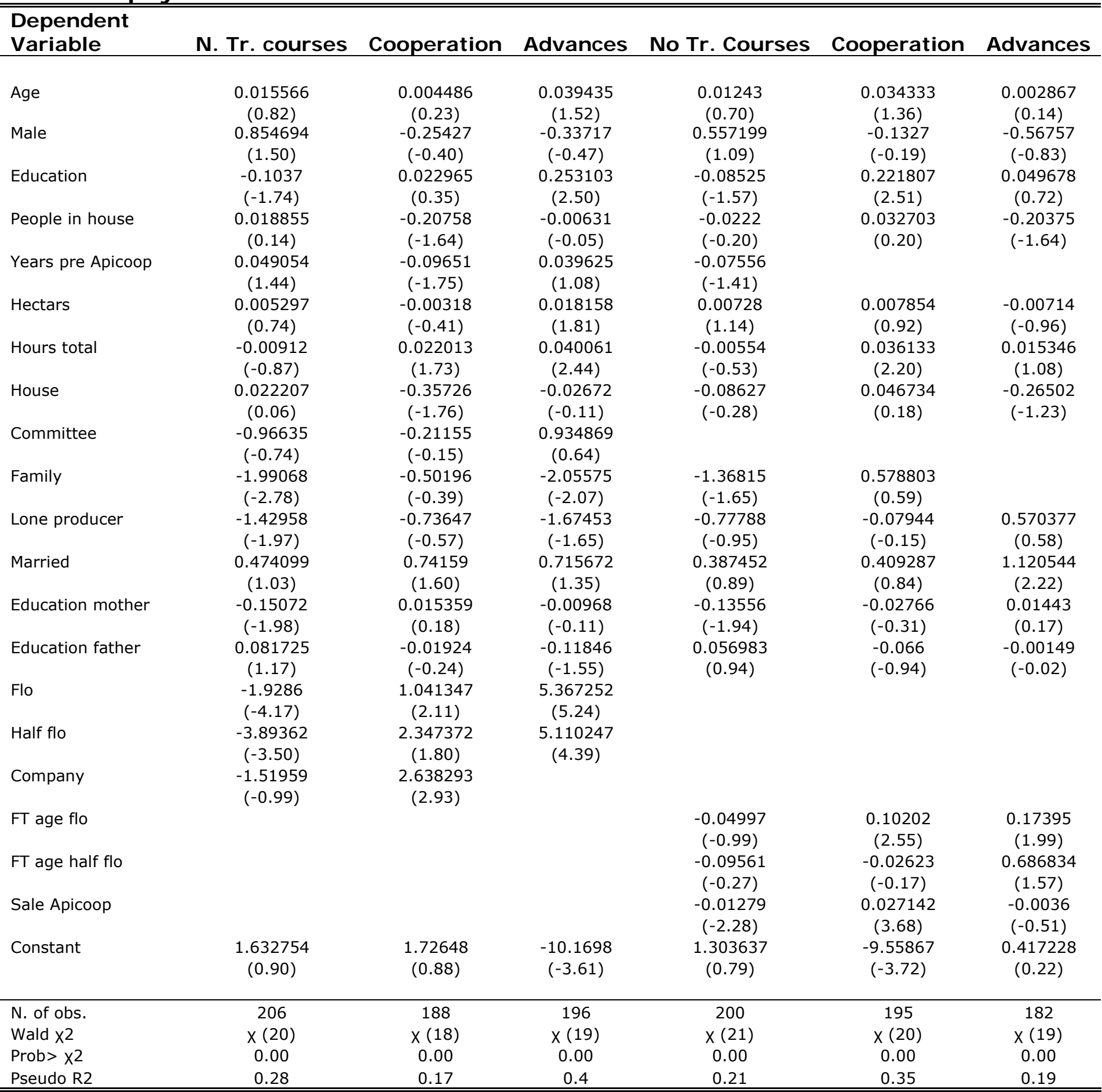

Legend: No training courses: DV equal to 1 if the producer attended training courses in the last three years; Cooperation: DV equal to 1 if the producer declares to cooperate with other producers in the area; Advances: DV equal to 1 if the producers received advanced payments on the product sold last year. For the legend of the other variables see Table 1. All regressions use DVs for the location and robust standard errors. Variables dropped for multicollinearity: Valdivia and Yearspreapicoop column 2. Variables dropped since they predict failure (dep. var=0) perfectly: Committee and Valdivia (column 3); Valdivia (column 4); Committee and Valdivia (column 5); Yearspreapicoop and Valdivia (column $5)$. 
Table 4. FT affiliation and productivity

\begin{tabular}{|c|c|c|c|c|c|c|}
\hline Methodology & OLS & $I V^{1}$ & $I V^{2}$ & OLS & OLS & OLS \\
\hline Age & $\begin{array}{c}1461.68 \\
(1.20)\end{array}$ & $\begin{array}{c}1430.049 \\
(1.17)\end{array}$ & $\begin{array}{c}1749.772 \\
(1.44)\end{array}$ & $\begin{array}{c}1412.735 \\
(1.16)\end{array}$ & $\begin{array}{c}1262.617 \\
(1.16)\end{array}$ & $\begin{array}{c}1129.963 \\
(1.06)\end{array}$ \\
\hline Male & $\begin{array}{c}29366.53 \\
(0.69)\end{array}$ & $\begin{array}{c}32409.79 \\
(0.81)\end{array}$ & $\begin{array}{c}29083.76 \\
(0.71)\end{array}$ & $\begin{array}{c}29004.14 \\
(0.69)\end{array}$ & $\begin{array}{c}9989.349 \\
(0.24)\end{array}$ & $\begin{array}{c}13533.15 \\
(0.33)\end{array}$ \\
\hline Education & $\begin{array}{c}9841.432 \\
(2.44)\end{array}$ & $\begin{array}{c}9727.202 \\
(2.36)\end{array}$ & $\begin{array}{c}10516.9 \\
(2.58)\end{array}$ & $\begin{array}{c}9645.027 \\
(2.32)\end{array}$ & $\begin{array}{c}7168.604 \\
(1.70)\end{array}$ & $\begin{array}{c}7051.898 \\
(1.82)\end{array}$ \\
\hline People in house & $\begin{array}{c}21212.95 \\
(1.73)\end{array}$ & $\begin{array}{c}17661.57 \\
(1.55)\end{array}$ & $\begin{array}{c}18482.59 \\
(1.58)\end{array}$ & $\begin{array}{c}16383.14 \\
(1.31)\end{array}$ & $\begin{array}{c}15888.28 \\
(1.34)\end{array}$ & $\begin{array}{l}16494 \\
(1.41)\end{array}$ \\
\hline Years pre Apicoop & $\begin{array}{c}479.9462 \\
(0.17)\end{array}$ & $\begin{array}{c}-418.222 \\
(-0.12)\end{array}$ & $\begin{array}{c}-877.652 \\
(-0.26)\end{array}$ & $\begin{array}{c}-659.778 \\
(-0.22)\end{array}$ & $\begin{array}{c}-123.802 \\
(-0.04)\end{array}$ & \\
\hline Hectars & $\begin{array}{c}1392.406 \\
(1.88)\end{array}$ & $\begin{array}{c}1406.562 \\
(1.97)\end{array}$ & $\begin{array}{c}1434.656 \\
(2.01)\end{array}$ & $\begin{array}{c}1429.959 \\
(2.06)\end{array}$ & $\begin{array}{c}1558.551 \\
(2.16)\end{array}$ & $\begin{array}{c}1526.899 \\
(2.07)\end{array}$ \\
\hline Hours total & $\begin{array}{c}-1278.8 \\
(-1.21)\end{array}$ & $\begin{array}{c}-1091.59 \\
(-1.08)\end{array}$ & $\begin{array}{c}-1144.96 \\
(-1.10)\end{array}$ & $\begin{array}{c}-1077.23 \\
(-1.05)\end{array}$ & $\begin{array}{c}-1189.69 \\
(-1.20)\end{array}$ & $\begin{array}{c}-1215.72 \\
(-1.17)\end{array}$ \\
\hline House & $\begin{array}{c}-7271.37 \\
(-0.85)\end{array}$ & $\begin{array}{c}-6153.53 \\
(-0.71)\end{array}$ & $\begin{array}{c}-4004.99 \\
(-0.47)\end{array}$ & $\begin{array}{c}-6032.88 \\
(-0.69)\end{array}$ & $\begin{array}{c}3751.059 \\
(0.52)\end{array}$ & $\begin{array}{c}4438.612 \\
(0.57)\end{array}$ \\
\hline Company & $\begin{array}{c}178068 \\
(2.27)\end{array}$ & $\begin{array}{c}182037.1 \\
(2.30)\end{array}$ & $\begin{array}{c}181836.1 \\
(2.39)\end{array}$ & & & \\
\hline Committee & & & & $\begin{array}{c}-180958 \\
(-2.32)\end{array}$ & $\begin{array}{c}42.98725 \\
(0.00)\end{array}$ & $\begin{array}{c}7557.346 \\
(0.12)\end{array}$ \\
\hline Family & $\begin{array}{c}26773.31 \\
(0.69)\end{array}$ & $\begin{array}{c}33588.98 \\
(0.77)\end{array}$ & $\begin{array}{c}28574.35 \\
(0.64)\end{array}$ & $\begin{array}{c}-148362 \\
(-1.87)\end{array}$ & $\begin{array}{c}8152.503 \\
(0.14)\end{array}$ & $\begin{array}{c}14491.53 \\
(0.24)\end{array}$ \\
\hline Lone producer & $\begin{array}{c}-11754.3 \\
(-0.35)\end{array}$ & $\begin{array}{c}-7377.43 \\
(-0.20)\end{array}$ & $\begin{array}{c}-8539.08 \\
(-0.23)\end{array}$ & $\begin{array}{c}-188880 \\
(-2.47)\end{array}$ & $\begin{array}{c}-16830.5 \\
(-0.30)\end{array}$ & $\begin{array}{c}-12418.2 \\
(-0.23)\end{array}$ \\
\hline Married & $\begin{array}{c}38823.37 \\
(1.48)\end{array}$ & $\begin{array}{c}46030.58 \\
(1.76)\end{array}$ & $\begin{array}{c}42445.18 \\
(1.61)\end{array}$ & $\begin{array}{c}48098.75 \\
(1.81)\end{array}$ & $\begin{array}{c}32344.73 \\
(1.20)\end{array}$ & $\begin{array}{c}31000.45 \\
(1.16)\end{array}$ \\
\hline Sale Apicoop & $\begin{array}{c}707.2168 \\
(2.07)\end{array}$ & & & & & \\
\hline Flo & & $\begin{array}{c}73320.94 \\
(1.63)\end{array}$ & $\begin{array}{c}92071.26 \\
(2.08)\end{array}$ & $\begin{array}{c}83186.04 \\
(2.65)\end{array}$ & $\begin{array}{c}50589.85 \\
(1.72)\end{array}$ & \\
\hline Half Flo & & $\begin{array}{c}15758.02 \\
(0.32)\end{array}$ & $\begin{array}{c}-1374.85 \\
(-0.04)\end{array}$ & $\begin{array}{c}21872.81 \\
(0.55)\end{array}$ & & \\
\hline Honey production & & & & & $\begin{array}{c}11.66654 \\
(2.76)\end{array}$ & $\begin{array}{c}12.51163 \\
(3.02)\end{array}$ \\
\hline$[\text { Honey production }]^{2}$ & & & & & $\begin{array}{c}-6.51 \mathrm{E}-06 \\
(-2.78)\end{array}$ & $\begin{array}{c}-6.97 \mathrm{E}-06 \\
(-3.04)\end{array}$ \\
\hline FT age Flo & & & & & & $\begin{array}{c}3039.482 \\
(1.83)\end{array}$ \\
\hline FT age half Flo & & & & & & $\begin{array}{c}-3087.28 \\
(-0.40)\end{array}$ \\
\hline Constant & $\begin{array}{c}-157930 \\
(-1.51)\end{array}$ & $\begin{array}{c}-153029 \\
(-1.39)\end{array}$ & $\begin{array}{c}-185688 \\
(-1.71)\end{array}$ & $\begin{array}{c}29074.59 \\
(0.25)\end{array}$ & $\begin{array}{c}-119713 \\
(-0.98)\end{array}$ & $\begin{array}{c}-110535 \\
(-0.87)\end{array}$ \\
\hline$N$ & 211 & 213 & 209 & 213 & 209 & 209 \\
\hline$F$ & $F(18,194)$ & $F(18,190)$ & $F(18,193)$ & $F(18,193)$ & $F(18,188)$ & $F(18,188)$ \\
\hline $\begin{array}{l}\text { Prob> F } \\
\text { Hansen's J statistic* }\end{array}$ & 0 & 0 & $\begin{array}{c}0 \\
7.302 X^{2}(3) \\
\text { P-val }=0.16287\end{array}$ & 0 & 0 & 0 \\
\hline Pseudo $\mathrm{R}^{2}$ & 0.38 & 0.39 & 0.38 & 0.38 & 0.43 & 0.43 \\
\hline
\end{tabular}

Legend: the dependent variable is productivity measured as value of honey production per hour worked. For the legend of the other variables see Table 1. All regressions use DVs for the location and robust standard errors.

1: Instruments for Flo: FTageflo;

2: Instruments for Flo: FTageflo, Cooperation, Advance Payment, No training courses.

Robust t-stat in parentheses. * Hansen's J statistic test of overidentifying restrictions. The joint null hypothesis is that the instruments are valid instruments, i.e., uncorrelated with the error term, and that the excluded instruments are correctly excluded from the estimated equation. 
Table 5. Treatment regression model

\begin{tabular}{|c|c|c|c|c|c|}
\hline \multicolumn{3}{|c|}{$\begin{array}{c}\text { MAIN EQUATI ON } \\
\text { (dependent variable: Productivity per hour) }\end{array}$} & \multicolumn{3}{|c|}{$\begin{array}{l}\text { TREATMENT EQUATION (dependent } \\
\text { variable: Flo) }\end{array}$} \\
\hline & $(1)$ & $(2)$ & & (1) & $(2)$ \\
\hline Age & $\begin{array}{r}3642.398 \\
(2.01)\end{array}$ & $\begin{array}{r}3154.087 \\
(1.93)\end{array}$ & Male & $\begin{array}{r}0.62947 \\
(2.11)\end{array}$ & $\begin{array}{r}0.60253 \\
(2.01)\end{array}$ \\
\hline Education & $\begin{array}{r}12486.05 \\
(2.22)\end{array}$ & $\begin{array}{r}4993.997 \\
(0.96)\end{array}$ & Married & $\begin{array}{r}0.000852 \\
(0.002)\end{array}$ & $\begin{array}{r}-0.02002 \\
(-0.09)\end{array}$ \\
\hline Hectars & $\begin{array}{r}1866.273 \\
(1.94)\end{array}$ & $\begin{array}{r}2518.979 \\
(2.91)\end{array}$ & Peopleinhouse & $\begin{array}{r}0.126561 \\
(2.23)\end{array}$ & $\begin{array}{r}0.112921 \\
(2.01)\end{array}$ \\
\hline Hours total & $\begin{array}{r}1764.776 \\
(1.44)\end{array}$ & $\begin{array}{r}419.7689 \\
(0.38)\end{array}$ & $\begin{array}{l}\text { Education } \\
\text { mother }\end{array}$ & $\begin{array}{r}-0.0447 \\
(-1.28)\end{array}$ & $\begin{array}{r}-0.04585 \\
(-1.31)\end{array}$ \\
\hline Year pre Apicoop & $\begin{array}{r}-2732.66 \\
(-0.73)\end{array}$ & $\begin{array}{r}845.4519 \\
(0.25)\end{array}$ & Education father & $\begin{array}{r}0.01 \\
(0.3)\end{array}$ & $\begin{array}{r}0.006944 \\
(0.21)\end{array}$ \\
\hline House & $\begin{array}{r}-16829.9 \\
(-0.78)\end{array}$ & $\begin{array}{r}6473.995 \\
(0.33)\end{array}$ & Committee & $\begin{array}{r}-6.24014 \\
(0.02)\end{array}$ & $\begin{array}{r}-12.1316 \\
(0.03)\end{array}$ \\
\hline Flo & $\begin{array}{r}209624.4 \\
(2.49)\end{array}$ & $\begin{array}{r}124489.8 \\
(1.91)\end{array}$ & Family & $\begin{array}{r}0.086591 \\
(0.16)\end{array}$ & $\begin{array}{r}0.226867 \\
(0.43)\end{array}$ \\
\hline Honey production & & $\begin{array}{r}34.17662 \\
(5.9)\end{array}$ & Single & $\begin{array}{r}-0.10485 \\
(-0.2)\end{array}$ & $\begin{array}{r}0.045886 \\
(0.09)\end{array}$ \\
\hline$[\text { Honey production }]^{2}$ & & $\begin{array}{r}-0.00047 \\
(-3.7)\end{array}$ & & & \\
\hline Constant & $\begin{array}{r}-279262 \\
(-1.78)\end{array}$ & $\begin{array}{r}-268420 \\
(-1.9)\end{array}$ & Constant & $\begin{array}{r}-1.04967 \\
(-1.64)\end{array}$ & $\begin{array}{r}-1.06971 \\
(-1.65)\end{array}$ \\
\hline $\begin{array}{l}\text { N. of obs. } \\
\text { Wald } x 2 \\
\text { Prob }>\text { X2 } \\
\text { LR test of indep. } \\
\text { eqns. }\left(\rho^{*}=0\right)\end{array}$ & & $\begin{array}{l}184 \\
20.30 \\
(0.00) \\
.86(.352)\end{array}$ & & & $\begin{array}{l}182 \\
67.51 \\
(0.00)\end{array}$ \\
\hline
\end{tabular}

* $\rho$ : correlation coefficient of the residuals of the two equations

Variable legend: see Table 1 


\section{Table 6.1 Differences among affiliated and non affiliated farmers (Propensity Score Matching)}

\begin{tabular}{lcccc}
\hline \hline Variable & n.treat & n.contr & ATT* & T-stat \\
\hline Honey per hour worked & 87 & 119 & $1.02 \mathrm{E}+05$ & 2.111 \\
Cooperation with local producers & 87 & 119 & 0.167 & 2.58 \\
Comparative standard of living & 87 & 119 & 0.438 & 1.436 \\
Professional self-esteem & 87 & 119 & 0.381 & 1.503 \\
Advances on payments & 87 & 119 & 0.242 & 3.309 \\
Share sold to Apicoop & 87 & 119 & 55.71 & 11.245 \\
\hline \hline
\end{tabular}

Note: ATT is the average treatment of the treated. Regressors in the ATT estimate: age, education, hectars, people in house, family, company, married, honey production and honey production squared. The balancing property is satisfied. Standard errors with bootstrapping and 50 replications.

Table 6.2 Propensity score estimate

(Dependent variable: Flo)

\begin{tabular}{lcr}
\hline \hline Regressor & Coeff. & T-stat \\
\hline Age & & \\
House & -0.00195 & -0.23 \\
Male & -0.00465 & -0.04 \\
Company & 0.499989 & 2.05 \\
Family owned & 0.029337 & 0.03 \\
Single & 0.364339 & 0.54 \\
Married & 0.185419 & 0.27 \\
Peopleinhouse & -0.26474 & -1.18 \\
Education mother & 0.113956 & 2.32 \\
Education father & -0.05083 & -1.32 \\
Constant & 0.001631 & 0.05 \\
& -0.95792 & -1.14 \\
\hline N. of observations & & \\
LR $x^{2}(9)$ & 176 & \\
Prob $>x^{2}$ & 25.43 & \\
Log likelihood & 0.002 & \\
Pseudo ${ }^{2}$ & -109.86812 & \\
\hline \hline
\end{tabular}


Appendix - not to be published

\section{Table A1. Summary Statistics of Socio-Demographic and Economic Variables}

\begin{tabular}{|c|c|c|c|c|}
\hline Variable & 1 Mean & Std. Dev. & Min & Max \\
\hline Male & 0.84 & 0.37 & 0 & 1 \\
\hline Age & 49.74 & 12.70 & 24 & 88 \\
\hline Education & 9.92 & 4.19 & 0 & 22 \\
\hline Education mother & 4.56 & 4.01 & 0 & 16 \\
\hline Education father & 4.66 & 4.27 & 0 & 18 \\
\hline Married & 0.65 & 0.48 & 0 & 1 \\
\hline Single & 0.20 & 0.40 & 0 & 1 \\
\hline Living together & 0.09 & 0.28 & 0 & 1 \\
\hline Divorced & 0.01 & 0.09 & 0 & 1 \\
\hline Separated & 0.03 & 0.16 & 0 & 1 \\
\hline Widowed & 0.03 & 0.18 & 0 & 1 \\
\hline People in house & 3.97 & 1.82 & 1 & 12 \\
\hline Children & 2.50 & 1.89 & 0 & 11 \\
\hline Hectars & 9.60 & 22.82 & 0 & 160 \\
\hline House & 0.87 & 0.34 & 0 & 1 \\
\hline Honey & 0.61 & 0.49 & 0 & 1 \\
\hline Other bees & 0.01 & 0.11 & 0 & 1 \\
\hline Agriculture & 0.13 & 0.34 & 0 & 1 \\
\hline Breeding & 0.06 & 0.25 & 0 & 1 \\
\hline Other activity & 0.20 & 0.40 & 0 & 1 \\
\hline Hours total & 42.26 & 17.54 & 2 & 105 \\
\hline Hours honey & 18.33 & 14.28 & 0 & 70 \\
\hline Hours agriculture & 7.55 & 13.45 & 0 & 60 \\
\hline Hours breeding & 3.94 & 10.59 & 0 & 70 \\
\hline Hours other & 9.93 & 17.34 & 0 & 89 \\
\hline Income necessary & $4,784,549$ & $3,605,721$ & 480,000 & $36,000,000$ \\
\hline Income total & $4,988,680$ & $11,400,000$ & 0 & $110,000,000$ \\
\hline Income honey & $2,109,031$ & $3,878,463$ & 0 & $40,000,000$ \\
\hline Income bees & 346,100 & $1,016,250$ & 0 & $10,000,000$ \\
\hline Income agriculture & 967,496 & $7,125,316$ & 0 & $100,000,000$ \\
\hline Income breeding & 247,122 & 841,495 & 0 & $9,000,000$ \\
\hline Income other & $1,350,009$ & $6,009,740$ & 0 & $80,000,000$ \\
\hline Other sources & 0.61 & 0.49 & 0 & 1 \\
\hline Sale Apicoop & 50.70 & 44.14 & 0 & 100 \\
\hline Sale retail & 31.61 & 40.09 & 0 & 100 \\
\hline Sale local intermediaries & 5.53 & 21.23 & 0 & 100 \\
\hline Sale traditional intermediaries & 8.06 & 25.68 & 0 & 100 \\
\hline Sale to international intermediaries & 0.86 & 8.18 & 0 & 92 \\
\hline Price Apicoop & 767 & 51 & 600 & 950 \\
\hline Price retail & 1,536 & 393 & 800 & 2,500 \\
\hline Price local intermediaries & 904 & 352 & 680 & 2,000 \\
\hline Price traditional intermediaries & 894 & 260 & 680 & 1,600 \\
\hline Price international intermediaries & 1,110 & 385 & 730 & 1,500 \\
\hline
\end{tabular}


Price per kilo

Honey production

Productivity per hour

Advance Payment

Percentage advance

Interests on advance

Training courses

Loan

Savings

Credit restriction

Wage Permanent worker

Wage Temporary worker

Happiness

Family satisfaction

Town

Santa Barbara

Paillaco

Rancagua

Mahiue

Years pre Apicoop

Flo

Half Flo

No Flo

FT age flo

FT age half flo

$\begin{array}{ll}1,040 & 466 \\ 3,232 & 6,134 \\ 141,302 & 280,286 \\ 0.20 & 0.40 \\ 25.07 & 19.13 \\ 0.61 & 3.27 \\ 0.29 & 0.46 \\ 0.76 & 0.43 \\ 0.55 & 0.50 \\ 0.17 & 0.38 \\ 821 & 332 \\ 935 & 258 \\ 5.55 & 1.70 \\ 6.89 & 1.70 \\ 0.23 & 0.42 \\ 0.21 & 0.41 \\ 0.19 & 0.40 \\ 0.11 & 0.31 \\ 0.04 & 0.18 \\ 2.58 & 7.054 \\ 0.46 & 0.50 \\ 0.12 & 0.33 \\ 0.42 & 0.49 \\ 3.05 & 4.76 \\ 0.47 & 1.34\end{array}$

2,500

60,000

3,333

1

100

20

1

1

1

1

1,477

1,900

9

10

1

1

1

1

1

29

1

1

1

20

8 